\title{
Temporal Variation of Reference Evapotranspiration in Lower River Kaduna Catchment Area, Nigeria
}

\author{
Auwal F. Abdussalam ${ }^{1}$ and Isa Zaharaddeen ${ }^{1 *}$ \\ ${ }^{1}$ Department of Geography, Kaduna State University, Kaduna, Nigeria.
}

Authors' contributions

This work was carried out in collaboration between the both authors. Authors AFA and IZ designed the research, analyzed the data and wrote the report. Both authors read and approved the final

manuscript.

Article Information

DOI: $10.9734 / A C R I / 2017 / 32984$

(1) Kazutoshi Okuno, Japan Association for Techno-innovation in Agriculture, Forestry and Fisheries (JATAFF), $\begin{array}{r}\text { Editor(s): } \\ \text { Jachiyo, } \\ \text { Japan. }\end{array}$

(2) Vilda Purutcuoglu, Department of Statistics, Middle East Technical University, Ankara, Turkey.

Reviewers:

(1) Lívia Cristina Pinto Dias, Federal University of Viçosa, Minas Gerais, Brazil. (2) Mairton Gomes da Silva, Federal University of Recôncavo of Bahia (UFRB), Cruz das Almas, BA, Brazil. (3) Rafael Aldighieri Moraes, University of Campinas, Brazil. Complete Peer review History: http://www.sciencedomain.org/review-history/19646

Original Research Article

Received $26^{\text {th }}$ March 2017

Accepted $12^{\text {th }}$ May 2017

Published 22 ${ }^{\text {nd }}$ June 2017

\begin{abstract}
Lower River Kaduna catchment area is located in north part of Nigeria where climate variability is pronounce such as high rainfall which result to drought, ground water scarcity and high surface water to evaporation. As such it is importance to investigate the temporal variation evapotranspiration of this area. Because it determined the atmospheric water demand in the catchment. Meteorological data were collected from Nigeria Meteorological Agency which include mean temperature and solar radiation for the period of 21 years (1994-2014). Makkink method of estimating evapotranspiration was used. Trend analysis, normality test and coefficient of variance were carried out respectively. The result revealed that the evapotranspiration has mean value of $4.22 \mathrm{~mm} \mathrm{day}^{-1}$, solar radiation has mean value of $21.48 \mathrm{MJ} \mathrm{m}^{-2}$ day $^{-1}$ and temperature has mean value of $32.07^{\circ} \mathrm{C}$. Both variables show a moderate variability in the catchment. Evapotranspiration and solar radiation show a negative annual trend while the temperature reveals positive annual trend. April to October has decrease of solar radiation, temperature and evapotranspiration while the remaining month has an increase trend. Seasonal trend shows that MAM and JJA have a decrease while SON and DJF have an increase in solar radiation and evapotranspiration. Seasonal trend of temperature show that MAM, JJA and SON has a decrease while DJF has an increase.
\end{abstract}


Keywords: Evapotranspiration; Nigeria; variability; radiation; temperature; temporal; Kaduna.

\section{INTRODUCTION}

As the water resources available for agriculture become limited due to population growth, drought and the evapotranspiration (ET). Apart of precipitation, evapotranspiration served as a major component of water use in agriculture grows. Thus, quantification of atmospheric demand of water requires knowledge of the evaporation of water from the earth and plant surfaces. The combination of these two phenomena, namely surface evaporation and transpiration, are collectively referred to as evapotranspiration [1]. Moreover, it is principal element of the hydrological cycle and an agro meteorological variable widely used in hydrology and agriculture [2]. The evapotranspiration rate from a reference surface, not short of water, is called the reference crop evapotranspiration or reference evapotranspiration and is denoted as ET. The reference surface is a hypothetical grass reference crop with specific characteristics [3]. ET is a complex phenomenon because it depends on several climatological factors such as temperature, solar radiation, wind and relative humidity among others [4,5]. However, the lower river Kaduna catchment area mighty be associated with the climate change [6] such as the high rainfall variability annually which result in drought, crop failures and reduced yields, flash floods, desertification, [6], groundwater shrinking and surface water subject to high evaporative losses and insufficient to meet the water demand [7]. This implies that, change in climate have significant impact on the availability of water resources [8, 9]. As such its crucial evapotranspiration to be studied most especially in the areas that classified to be hotspot under the changing climate.Despite the climate variability in the catchment, agriculture is the major occupation and source of food. An estimation of potential water requirements for agriculture will permit improved planning and allocation of water resources among the municipal, industrial, environmental and agricultural sectors [10]. Nonetheless, up to date few studies have been conducted for ET estimation in the northwest region of Nigeria especially in Kaduna State for examples $[11,12]$. This research therefore intends to bridge this gap, which aimed to estimate the ET in lower River Kaduna catchment so as to assess it temporal variation.

\section{MATERIALS AND METHODS}

The study area lies between latitudes $10.245^{\circ} \mathrm{N}$ and $10.808^{\circ} \mathrm{N}$ and longitude $7.021^{\circ} \mathrm{E}$ and $7.786^{\circ} \mathrm{E}$ (Fig. 1). The catchment covered Kaduna North and South Local Government and some part of Igabi and Chikun Local Government. The lower Kaduna River catchment is within the highland climatic zone of Nigeria, with an elevation of $591 \mathrm{~m}$. The mean evaporation loss annually is $2448 \mathrm{~mm}$. water from the catchment drained by River Kaduna through its tributaries such as Rivers Rigachikun, Ruza and Romi. Kaduna River takes its source from Jos Plateau state and flows for about $210 \mathrm{~km}$ to Kaduna Town. It crosses the town, dividing it into North and South areas. The River flows beyond Kaduna for about $100 \mathrm{~km}$ into the Shiroro dam and continues until it finally discharges into the River Niger about 200 km from Shiroro dam [13]. Land use in the catchment include built-up area, agricultural area which include mechanized farming such as the Wushishi farms, Niyya farms, etc had also taken over large portions of land for cultivation. Most of the natural savanna wood land has been cleared. What seems to be left of the forests is the forest reserve of Afaka. Water bodies such as dams or lakes due to construction of earth dams under the policy of Kaduna state government to encourage irrigation farming in the state [14] and river Kaduna and its tributaries as mention earlier.

\subsection{Meteorological Data}

Mean daily temperature and solar radiation data were obtained from Nigerian Meteorological Agency (NiMet) Kaduna, for the period of 21 years from 1994-2014. The station is located in international airport Kaduna (Latitude 1002', Longitude $07^{\circ} 19^{\prime}$ and elevation of about $645 \mathrm{~m}$. This station was chosen because it is within the catchment area.

\subsection{Method Estimation of Daily Reference Evapotranspiration}

Some of the method such as Penman-Monteith required many meteorological data. Also, the data quality of all-weather parameters is poor and limited in most of the station [3] especially in developing country [15]. However, models that use readily limited available weather data are therefore preferable [16]. These include Makkink (1957), Turc (1961), Priestley and Taylor, (1972), and Doorenbos and Pruitt (1977). For example, 
the difference between Priestley and Makkink is that, instead of using net radiation, Makkik uses incoming solar radiation which offers a potential advantage over Priestly-Taylor [17]. Also it suited the available meteorological data obtained for this study. Therefore makkink method was consider for this research.

Makkink (1957) method was adopted in this research using only temperature and solar radiation parameters [18]. The Makkink equation is as given below:

$$
E T=0.61\left(\frac{\Delta}{\Delta+\gamma}\right)\left(\frac{R s}{\lambda}\right)-0.12
$$

Where, $\Delta$ is the slope vapour curve $\left(\mathrm{kPa}^{\circ} \mathrm{C}^{-1}\right)$; $\mathrm{y}$ is the psychrometric constant $\left(\mathrm{kPa}^{\circ} \mathrm{C}^{-1}\right)$; Rs is the solar radiation of the crop surface $\left(\mathrm{MJ} \mathrm{m}^{-2}\right.$ day $\left.^{-1}\right)$; and $\lambda$ is the latent heat of vapour $\left(\mathrm{MJ} \mathrm{kg}^{-1}\right.$ ).

Normality test, coefficient of variance and trend analysis using Mann-Kendall and Sen's Slope of solar radiation $\left(\mathrm{MJ} \mathrm{m}^{-2} \mathrm{day}^{-1}\right)$, temperature $\left({ }^{0} \mathrm{C}\right)$ and ET ( $\mathrm{mm} \mathrm{day}^{-1}$ ) were carried out based on monthly, annual and seasonal to understand the variability in the catchment. Both analyses were computed using AddinSoft XLSTAT software.

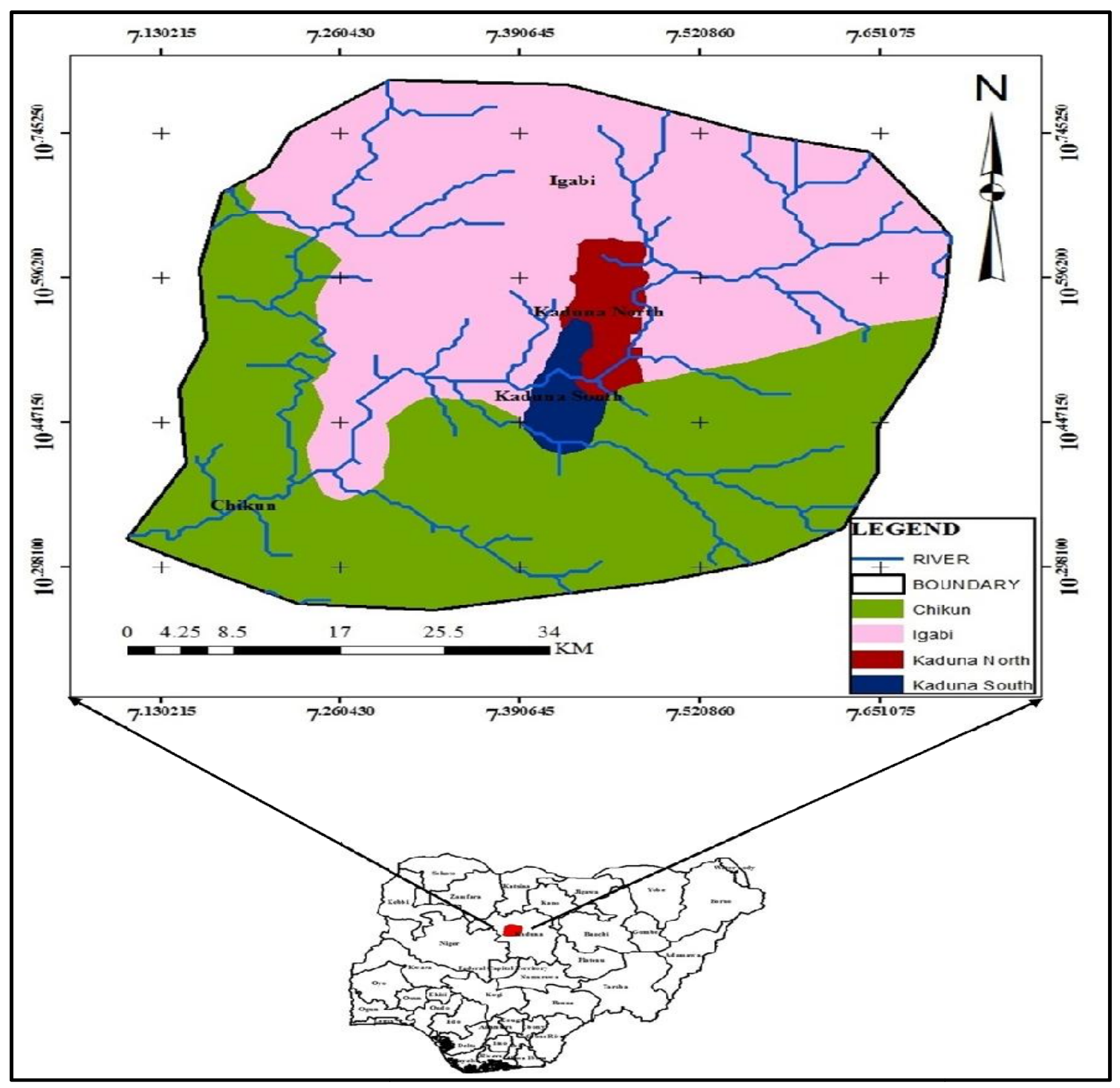

Fig. 1. Map of the lower River Kaduna catchment area Source: Author (2016) modified shape file from. www.digitalglove.com 


\section{RESULTS AND DISCUSSION}

\subsection{Trend and Variability of Rs, Tmean and ET}

The results of descriptive statistical analysis of the solar radiation (Rs), daily mean temperature (Tmean), and ET are presented in Table 1. Kurtosis is a measure of data peakness or flatness relative to normal distribution. Normal distribution has zero kurtosis. Positive kurtosis indicates peaked distribution, while negative kurtosis indicates flat distribution. The Rs, Tmean, and ET data exhibited flat distribution. The Rs and ET data exhibited left skewed while the Tmean exhibited right skewed. The coefficient of variance which measures the variability of the climate elements, the Rs, Tmean and ET data set in the studies accounts for more than 0.1 coefficient of variance, which indicated moderate variability ( $\mathrm{CV}>0.1$ or $10 \%$ and $<0.9$ or $90 \%$ ). The climate variability in lower river Kaduna catchment area showed similarities with other studies such as $[15,19]$.

Table 1. Normality test analysis of Rs, Tmean and ET

\begin{tabular}{llll}
\hline $\begin{array}{l}\text { Descriptive } \\
\text { statistic }\end{array}$ & Rs & Tmean & ET \\
\hline Minimum & 4.50 & 21.00 & 0.72 \\
Maximum & 31.20 & 43.00 & 6.37 \\
Range & 26.70 & 22.00 & 5.65 \\
Mean & 21.48 & 32.07 & 4.22 \\
Variance & 15.19 & 10.30 & 0.72 \\
STD & 3.90 & 3.21 & 0.85 \\
CV & 0.18 & 0.10 & 0.20 \\
Skewness & -0.23 & 0.11 & -0.20 \\
Kurtosis & -0.51 & -0.33 & -0.62 \\
Anderson-darling & & \\
A & 44.483 & 24.855 & 46.750 \\
p-value & $<0.0001$ & $<0.0001$ & $<0.0001$ \\
Alpha & 0.05 & 0.05 & 0.05 \\
\hline \multicolumn{4}{c}{ Source: Author (2016) } \\
\end{tabular}

A typical result of Anderson-Darling (AD) test is presented in Table 1. The hypotheses for the AD normality test are: $\mathrm{H} 0$ : sample values come from a normally distributed data and $\mathrm{H} 1$ : sample values come from a non-normally distributed data. If the normal distribution fits the data, the (AD) statistic will be small and the p-value will be greater than the chosen alpha-level. From the results of $(A D)$ normality test, there is insufficient evidence to suggest that Rs, Tmean and ET data of the study area are from a normally distributed data, since the $p$ value is less than the significant level (0.05). This result is in line with that of [15] in their studies on new data set for applied climatological research. It also confirmed the statement of [19] that the characteristic of meteorological data are not from normal distributed data.

\subsection{Solar Radiation}

Fig. 2, presented the daily time series of solar radiation which shown a negative trend in lower river Kaduna catchment area. This implies that there is decrease in the amount of solar radiation. Similarly, the monthly (Fig. 3) and the annual (Fig. 4 and Table 2) time series of solar radiation revealed a negative trend. This negative trend of solar radiation is in line with the result of $[15,20]$ that solar radiation is on decrease in Kaduna. Similarly, [21] observed a decrease of solar radiation in Ibadan. This may be due to the influence of the dry, dusty tropicalcontinental air mass and the warm, tropicalmaritime air mass which control the atmospheric conditions of Nigeria [4]. Also in Table 2 shows that the month of April to October has decreased Rs both from Mann-Kendall and Sen's Slope while the other months have an increased trend. Seasonal trend (Table 2) shows that MAM and JJA has a decrease in Rs while SON and DJF have an increase in Rs. This can be implied that, the MAM is season that mostly the catchment experienced onset of rainfall while the JJA is the season of rainfall, therefore due to the increased rainfall and cloud cover may result to the decreased of Rs during these seasons. SON is the season when the catchment experienced cessation of rainfall and there is little or no cloud cover during this period while the DJF is peak of dry season where there is no cloud cover and absences of rainfall these can result the increase of Rs.

\subsection{Mean Temperature}

Both the daily (Fig. 5), monthly (Fig. 6) and annual (Fig. 7 and Table 2) mean temperature exhibited a positive trend. These imply that, there is increased temperature in lower river Kaduna catchment area from 1994 to 2014. Also in Table 2 shows that the month of April to October has negative trend from both Mann-Kendall and Sen's while the other months have a positive trend. Seasonal trend (Table 2) shows that MAM, JJA and SON have a decrease in Tmean while DJF has an increase in Tmean. During the seasons (MAM, JJA and SON), the catchment normally experienced rainfall. Therefore, due to 
the presence of rainfall, may lead to the growth of cooling phenomena i.e. vegetation. Similarly, cloud cover is also presence during these seasons. These may result to the decrease of
Tmean during these seasons. The DJF is peak of dry season where there is no cloud cover and absences of rainfall and these can result the increased Tmean.

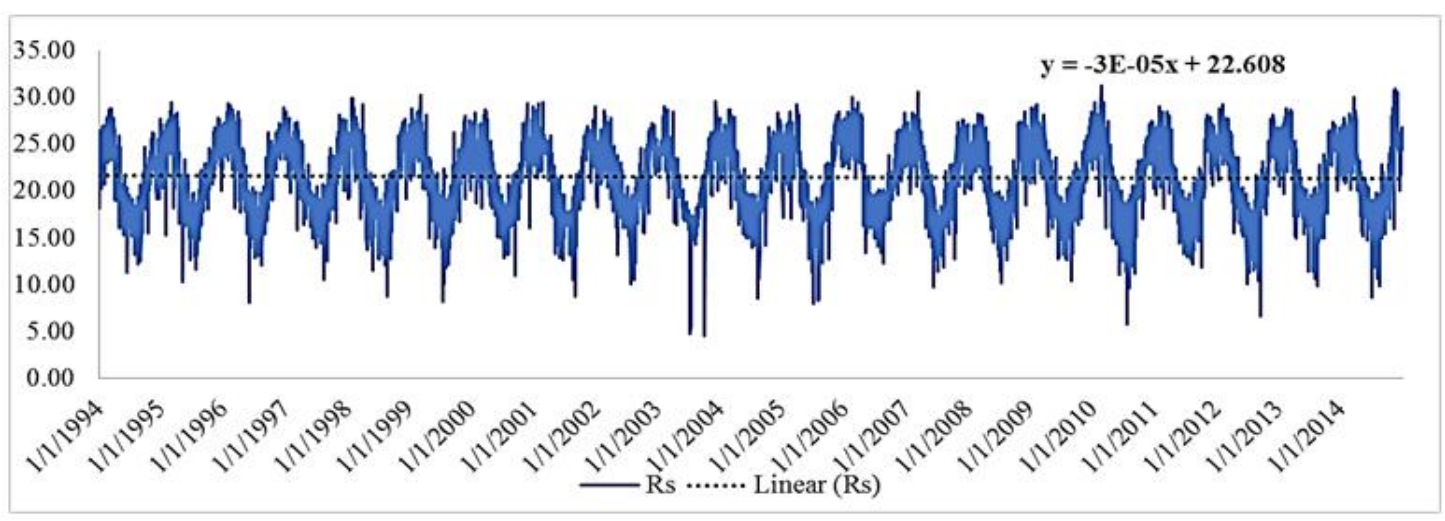

Fig. 2. Daily solar radiation of lower river Kaduna catchment area

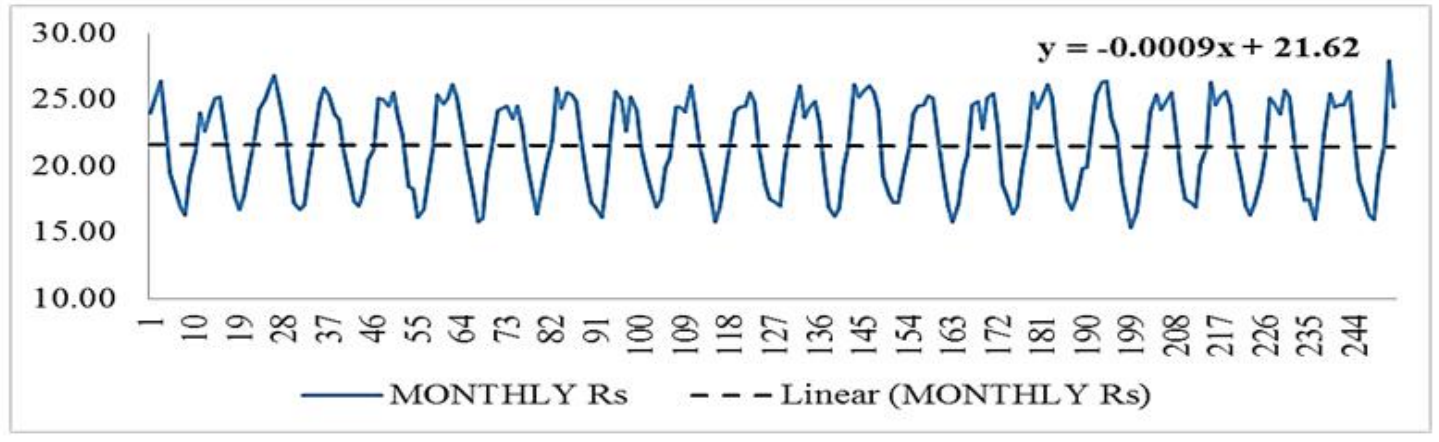

Fig. 3. Monthly mean solar radiation of lower river Kaduna catchment area

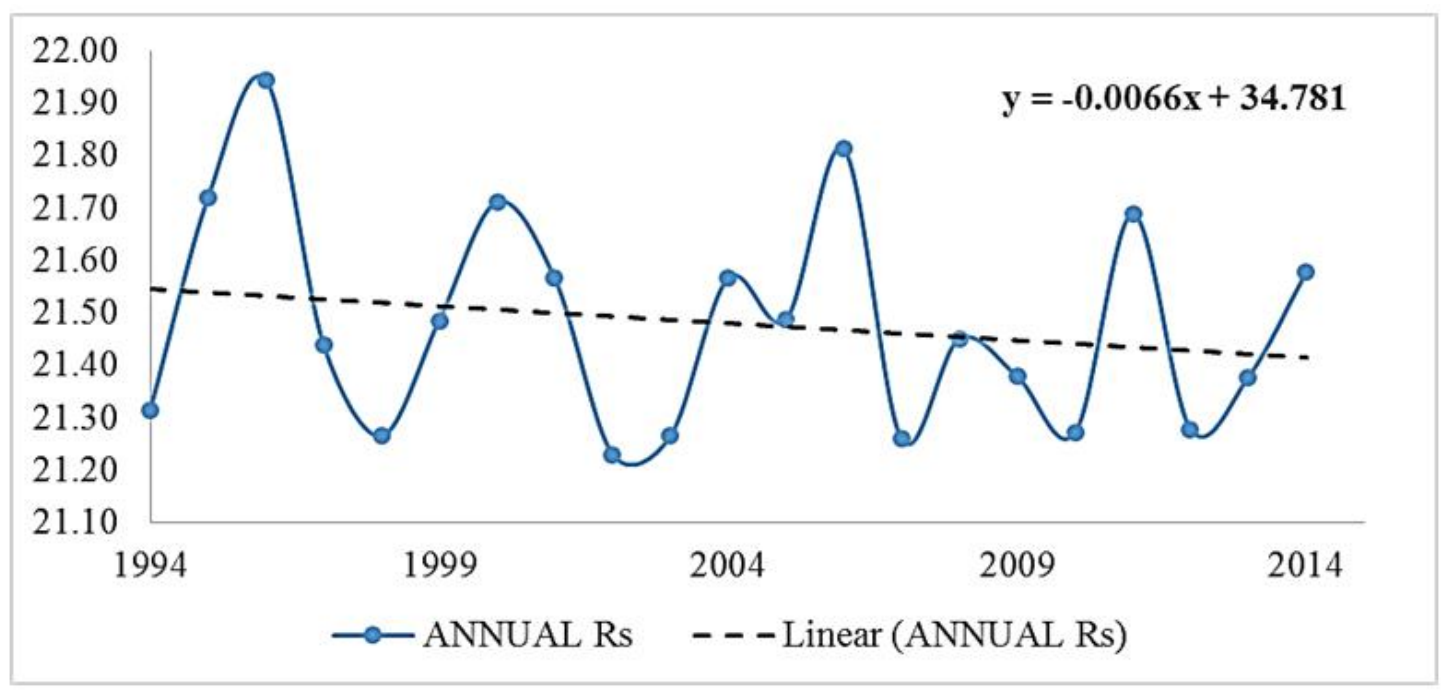

Fig. 4. Annual mean solar radiation of lower river Kaduna catchment area 
However, the annual time series (Fig. 7) shows that, 2006 has the highest mean temperature while 2008 has the lowest mean temperature, this revealed that the 2006 was the warmest while the 2008 was the coolest year in lower river Kaduna catchment area during years of studies.

The increased mean temperature in this study shows a similarities with the other studied such as $[22,23]$, they revealed that there is an increase (positive trend) in temperature in Nigeria, [24], reported that, there is an increase in temperature in the semi-arid region of Sokoto, Katsina, Kano, Nguru and Maiduguri, and [19] reported that Kaduna state experienced a positive trend in mean temperature. Also many regional studies have also found a positive trend in temperature, although the changes vary slightly from one region to another $[25,26,27,28$, 29]. This warmness of temperatures may lead to increased evapotranspiration, drought and desertification [24], and it can lead to impact on levels of human thermal comfort and the length of the discomfort season [30], the phenology of a range of plant and animal species [31], the possible re-emergence of some tick-borne diseases [32] and increase meningitis cases in northwest Nigeria in the future [33].

\subsection{Evapotranspiration (ET)}

The estimated ET was presented below in Figs. 8, 9 and 10. The annual ET (Fig. 10) shows that the highest ET value was experienced in 2002 followed by 2006 while 2008 have the lowest ET value. Similar temporal negative trend was observed for both the daily (Fig. 8), monthly (Fig. 9), and annual (Fig. 10 and Table 2) of ET time series with that of solar radiation. Also in Table 2 shows that the month of April to October has negative trend both while the other months have a positive trend. Seasonal trend (Table 2) shows that MAM and JJA have a decrease in ET while SON and DJF have an increase in ET. These

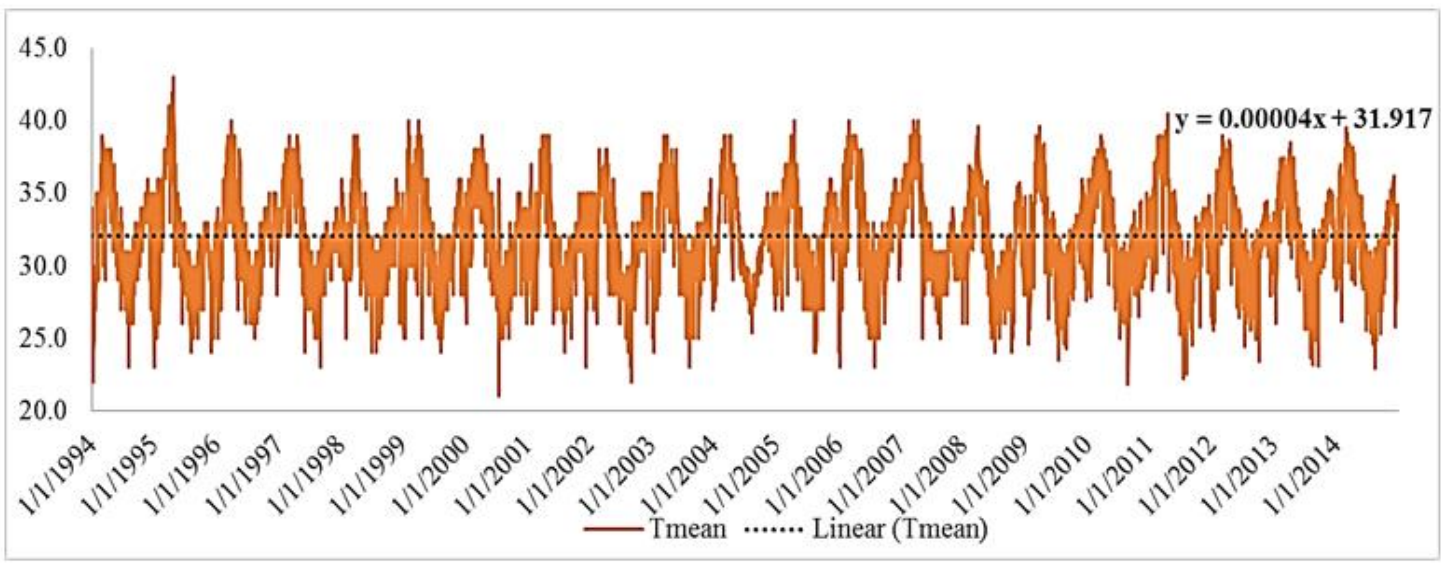

Fig. 5. Daily mean temperature of lower river Kaduna catchment area

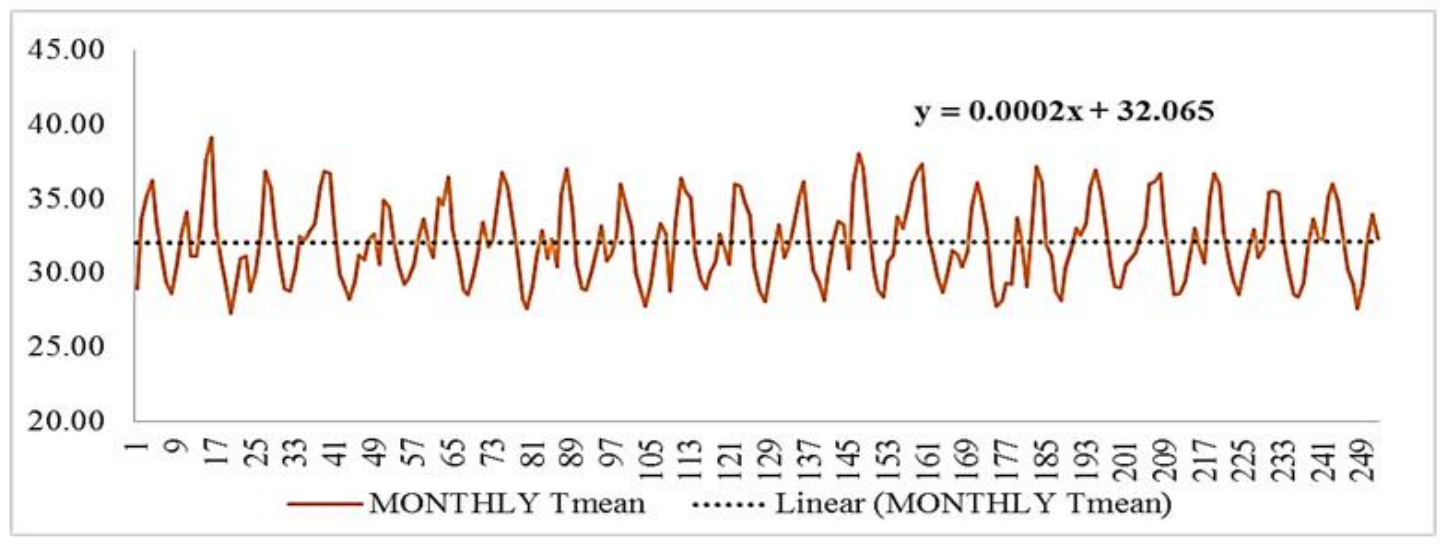

Fig. 6. Monthly mean solar radiation of lower river Kaduna catchment area 
imply that there is decreased vaporization of water to the atmosphere during MAM, JJA and annual. Furthermore, similar results were obtained from previous studies such as $[34,35$, $36,37,38,39]$. The decreased ET potentially could be due to confounded effects of change in other atmospheric variables that influenced ET. Thus decrease in solar radiation was most likely responsible for decreased potential ET [40].
Decrease in solar radiation was strongly related to the decreased trend in ET $[37,38,41,42,43$, 44]. This is because for evapotranspiration to take place, energy is required to change the state of the molecules of water from liquid to vapour. This energy is provided by solar radiation incident on the earth's surface [45]. These confirmed the results found in lower river Kaduna catchment area.

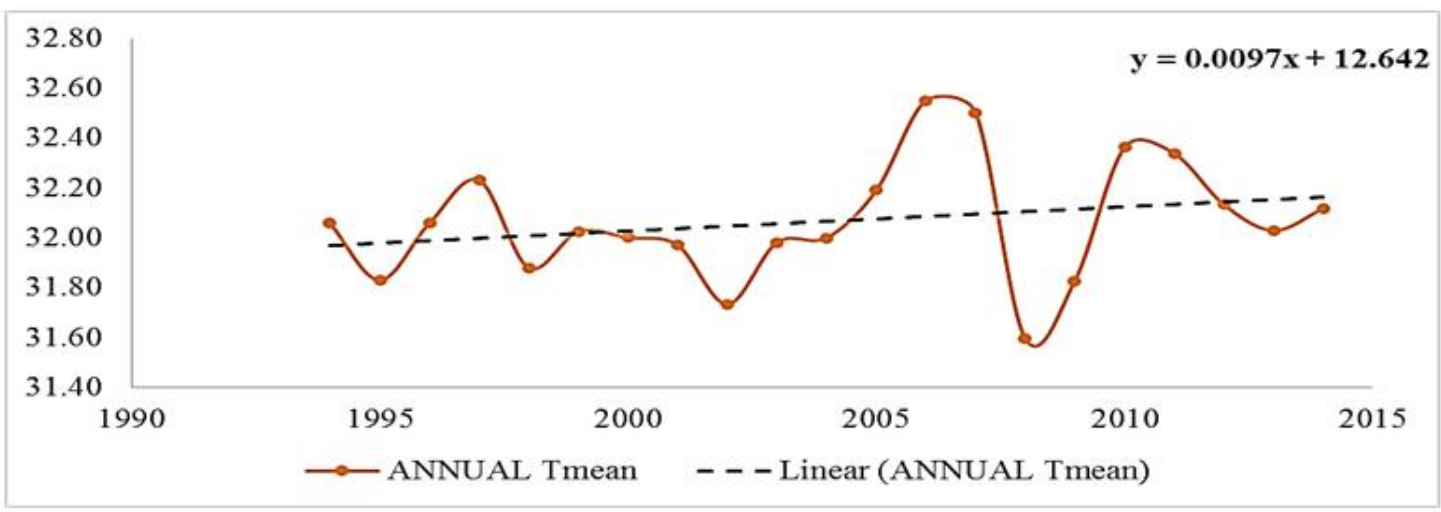

Fig. 7. Annual mean solar radiation of lower river Kaduna catchment area

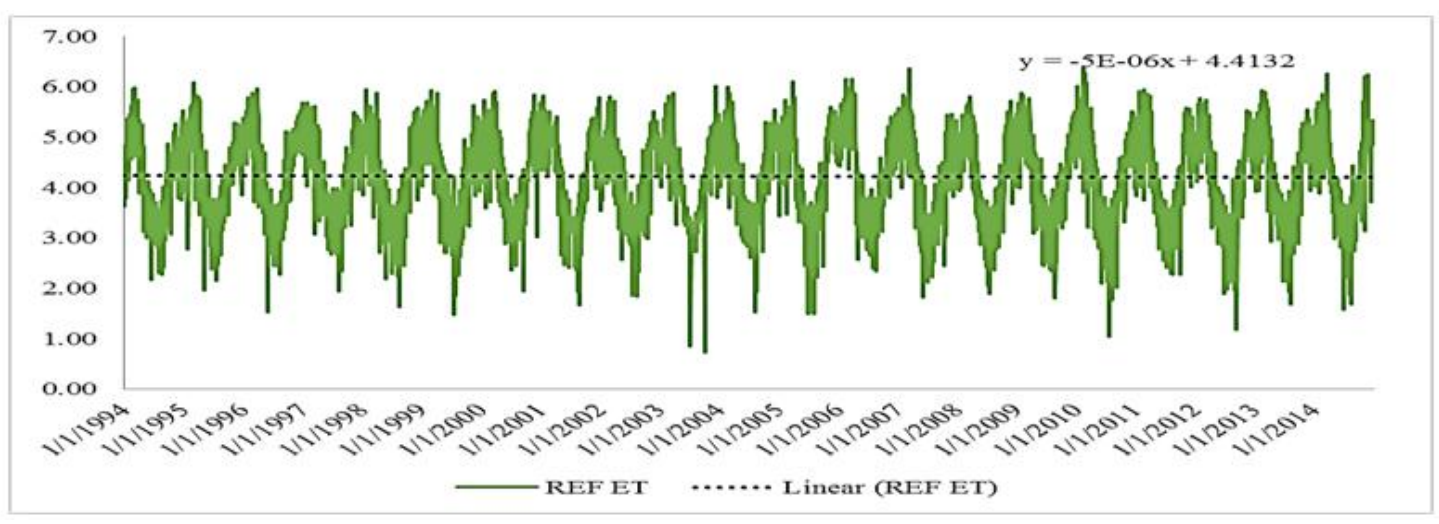

Fig. 8. Daily ET of lower rive Kaduna catchment area

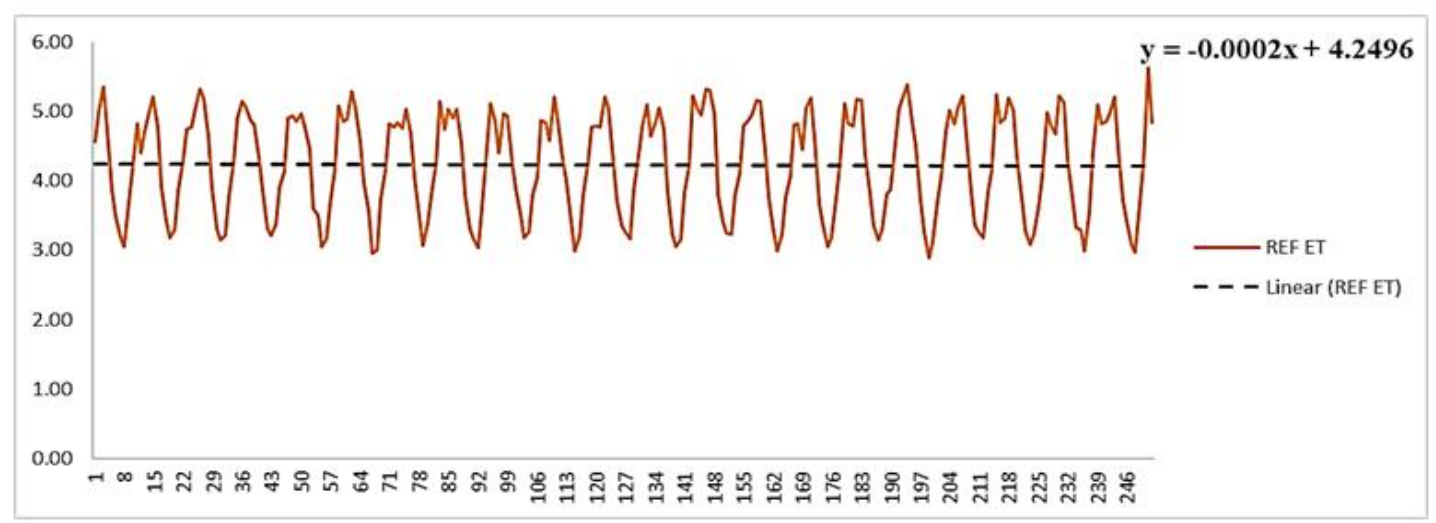

Fig. 9. Monthly ET of lower river Kaduna catchment area 


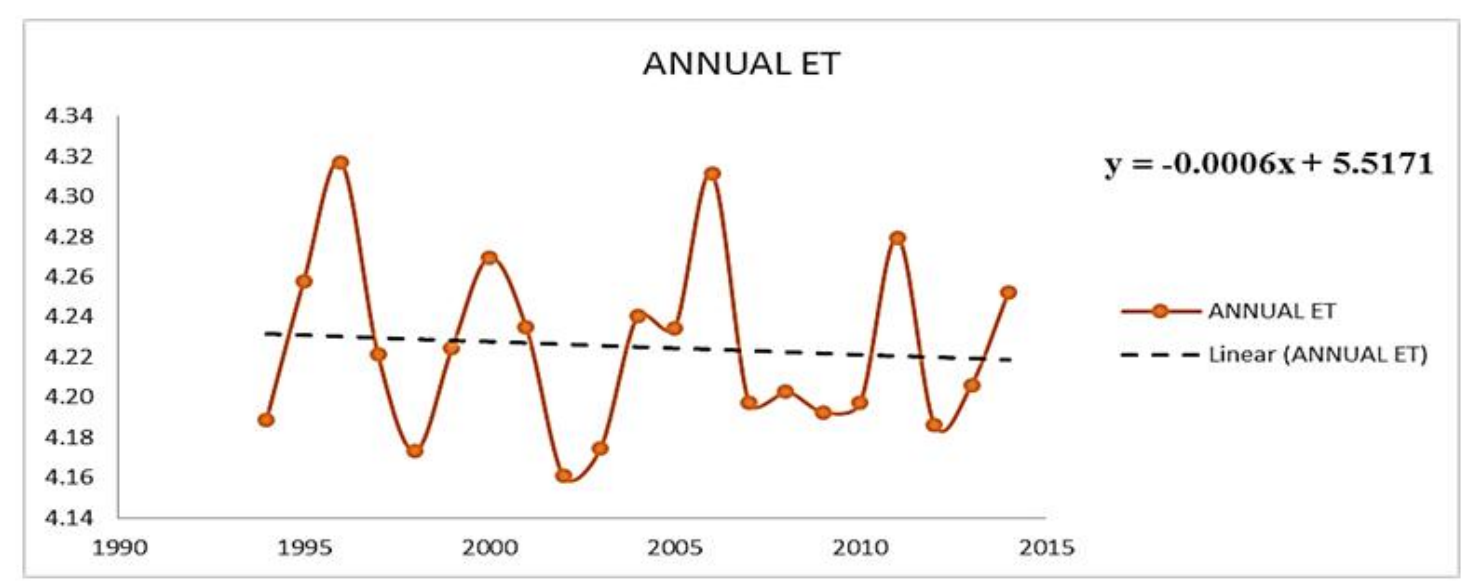

Fig. 10. Annual ET of lower river Kaduna catchment area

Table 2. Trend analysis of Rs, Tmean and ET in lower river Kaduna catchment

\begin{tabular}{lllllll}
\hline \multirow{2}{*}{ Time series } & \multicolumn{3}{l}{ Mann-Kendall trend } & \multicolumn{3}{l}{ Sen's slope estimate } \\
\cline { 2 - 7 } & Rs & Tmean & ET & Rs & Tmean & ET \\
\hline January & 0.0302 & 0.7549 & 0.0906 & 0.0010 & 0.0450 & 0.0011 \\
February & 0.4530 & 1.6004 & 1.0569 & 0.0177 & 0.1065 & 0.0082 \\
March & 0.9965 & 0.3021 & 0.5133 & 0.0244 & 0.0094 & 0.0043 \\
April & -1.2985 & -0.9667 & -1.4193 & -0.0448 & -0.0384 & -0.0114 \\
May & -1.8420 & -1.2084 & -2.3252 & -0.0370 & -0.0279 & -0.0089 \\
June & -1.4193 & -0.7855 & -1.5400 & -0.0261 & -0.0176 & -0.0063 \\
July & -0.0604 & -0.7855 & -0.0906 & -0.0009 & -0.0160 & -0.0007 \\
August & -1.0272 & -0.0906 & -1.1777 & -0.0244 & -0.0048 & -0.0049 \\
September & -1.2985 & -0.4834 & -1.0569 & -0.0291 & -0.0059 & -0.0049 \\
October & -0.2718 & -0.6945 & -0.8757 & -0.0105 & -0.0175 & -0.0032 \\
November & 1.0569 & 0.8757 & 0.9965 & 0.0455 & 0.0334 & 0.0104 \\
December & 0.0000 & 0.8757 & 0.3322 & 0.0001 & 0.0258 & 0.0025 \\
ANNUAL & -0.8153 & 0.8757 & -0.0302 & -0.0041 & 0.0094 & -0.0002 \\
March-April-May (MAM) & -0.9361 & -0.6945 & -0.9361 & -0.0194 & -0.0174 & -0.0069 \\
June-July-August (JJA) & -1.3589 & -0.8757 & -1.6608 & -0.0179 & -0.0110 & -0.0041 \\
September-October-November (SON) & 0.2718 & -0.1510 & 0.3322 & 0.0093 & -0.0048 & 0.0013 \\
December-January-February (DJF) & 0.5133 & 2.5063 & 0.8757 & 0.0155 & 0.0938 & 0.0045 \\
\hline
\end{tabular}

Cloudless condition during DJF allows a high percentage of solar radiation to reach the earth surface, hence warmer temperature occurs. On the other hand, less solar radiation reaches the surface during cloudy sky and cooler temperature occurs especially during JJA. The temporal distribution of ET especially during the month of April to October is controlled by solar radiation and temperature, similar to that of November to March. The seasonality of the Rs has more controlled ET over Tmean. The variation of temperature with solar radiation is due to the fact that surface temperature is the reflection of both the duration and intensity of solar radiation [46].

\section{CONCLUSION}

The sustainable development of any region is of paramount importance to the planning, development and management of its water resource. The ET of lower river Kaduna catchment area was estimated and shows a moderate variability similar to solar radiation and Tmean. Also it reveals that, there is annual decrease of ET in lower river Kaduna catchment area. The ET and Rs have similar temporal distribution patterns in the catchment. The result reveals that, the temporal variation pattern of ET is determined by the temporal variation of the Rs in the catchment. Based on the results we 
recommend the following for future research: other possible time series model should be consider which can capture the nonlinearity in the data such as auto-regressive or moving average model with related references. Also, long time data should be considered in other to predict for the future.

\section{ACKNOWLEDGEMENT}

We sincerely thank NIMET Kaduna for providing meteorological data. We also thank the reviewers for their invaluable comments and useful suggestions.

\section{COMPETING INTERESTS}

Authors have declared that no competing interests exist.

\section{REFERENCES}

1. Farahani HJ, Howell TA, Shuttleworth WJ, Bausch WC. Evapotranspiration: Progress in measurement and modelling in agriculture. American Society of Agricultural and Biological Engineers. 2007;50(5):1627-1638.

2. Sabziparvar AA, Tabari $H$, Aeini A, Ghafouri M. Evaluation of class A pan coefficient models for estimation of reference crop evapotranspiration in coldsemi arid and warm arid climates. Water Resources Management. 2010;24(5):909_ 920.

3. Allen RG, Pereira SL, Raes D, Smith M. Crop evapotranspiration-guidelines for computing crop water requirements. FAO Irrigation and Drainage. 1998;56.

4. Audu MO, Isikwue BC. Survey of the reflectivity of the Earth's Atmosphere over some selected cities in Nigeria. International Research Journal of Pure and Applied Physics. 2015;3(1):54-64.

5. Shanka VA. User friendly tool for performance evaluation of different reference evapotranspiration methods. World Academy of Science, Engineering and Technology. 2013;4:202-207.

6. Peter EA. An assessment of rainfall and temperature variations in selected stations in parts of Northern Nigeria. Unpublished PhD thesis, University of Jos. 2012;214.

7. Othoman A, Flores C, Jinno K, Tsutsumil A. Comparison of several reference evapotranspiration methods for Itoshima
Peninsula Area, Fukuoka, Japan. Memoirs of the Faculty of Engineering. 2006;66(1): $1-14$.

8. Shahid S. Impacts of climate change on irrigation water demand in Northwestern Bangladesh. Climatic Change. 2011; 105(3-4):433-453.

9. Oluwaseun Al, Philip GO, Ayorinde AO. Re-examination of the BMN model for estimating evapotranspiration. International Journal of Agriculture and Forestry. 2012; 2(6):268-272.

10. Kaleem UM, Zaigham H, Saim M. Spatial distribution of reference and potential evapotranspiration across the Indus Basin irrigation system. Pakistan. International Water Management, Institute Lahore. 2001;62.

11. Oluwaseun AI, Philip GO, Ayorinde AO. Evaluation of four ET models for IITA stations in Ibadan, Onne and Kano, Nigeria. Journal of Environment and Earth Science. 2014;4(5):89-97.

12. Maina MM, Amin MS, Aimrun W, Asha TS Evaluation of different ET calculation methods: A case study in Kano State, Nigeria. Philipp Agric Scientist. 2012; 58(2):394-399.

13. Bamgboye OA. Brief on the field trip to Kaduna water supply system; Background Reference Session 19 Field Trip; TOTIWRM 2004 Program.

14. Ndabula C. Assessment of land use/ Landover changes in Kaduna metropolitan area using remote sensing and geographic information system techniques. Unpublished M.Sc Thesis, Abu Zaria. 2006;137.

15. Zaharaddeen I, Ibrahim IB. New data set for applied climatological research in former Kaduna State. Fuelling New Directions for Sub-Sahara African Advancement: Multi-disciplinary approach. Sub-Sahara African Academic Research Publications. 2016;5:82-92.

16. Tabari $\mathrm{H}$, Marofi $\mathrm{S}$. Changes of pan evaporation in the west of Iran. Water Resources Management. 2011;25(1):97111.

17. Bander A. Assessment of evapotranspiration models under Hyper Arid environments. Unpublished MSc thesis, University of Guelph, Guelph, Ontario, Canada. 2012;124.

18. Nurul NA, Sobri $H$, Shamsuddin S. Comparison of different methods in 
estimating potential evapotranspiration at Muda Irrigation Scheme of Malaysia. Journal of Agriculture and Rural Development in the Tropics and Subtropics. 2012;115(2):77-85.

19. Attah DA. Climate variability and its impact on water resources of lower Kaduna River catchment Nigeria. Unpublished Phd Thesis, ABU Zaria. 2013;189.

20. Hassan I, Onimisi MY. Assessment of the global solar energy potential at Nigerian Defence Academy (NDA) permanent site Afaka Kaduna, Nigeria. American Chemical Science Journal. 2013;3(3):232246.

21. Audu MO, Isikwue BC, Eweh EJ. Evaluation of seasonal and annual variations of evapotranspiration with climatic parameters in Ibadan, Nigeria. Journal of Earth Sciences and Geotechnical Engineering. 2015;5(2):6979.

22. Akinsanola AA, Ogunjobi KO. Analysis of rainfall and temperature variability over Nigeria. Global Journal of Human-Social Science. 2014;14(3):1-19.

23. Amadi SO, Udo SO, Ewona IO. Trends and variations of monthly mean minimum and maximum temperature data over Nigeria for the period 1950-2012. International Journal of Pure and Applied Physics. 2014;2(4):1-27.

24. Adefolalu DO. Climate change and economic sustainability in Nigeria. Paper presented at the International Conference on Climate Change and Economic Sustainability held at Nnamdi Azikiwe University, Enugu, Nigeria. 2007;1-12.

25. Abatzoglou JT, Redmond KT, Edwards LM. Classification of regional climate variability in the State of California. Journal of Applied Meteorology and Climatology. 2009;48(8):1527-1541.

26. Karaburun A, Demirci A. Kora F. Analysis of spatially distributed annual, seasonal and monthly temperatures in Marmara Region from 1975-2006. Ozean Journal of Applied Sciences. 2012;5(2):131-149.

27. Ustaoglu B. Trend analysis of annual mean temperature data using Mann-Kedall rank correlation test in Catalca - Kocaeli Peninsula, North West of Turkey for the period of 1970-2011. IBAC. 2012;2:276287.

28. Liu WX, Li XD, Shen ZG, Wang DC, Wai OW, Li SY. Multivariate statistical study of heavy metal enrichment in sediments of the Pearl River Estuary. Environmental Pollution. 2003;51(3):377-388.

29. Abudaya M. Seasonal and spatial variation in Sea surface temperature in the SouthEast Mediterranean Sea. Journal of Environment and Earth Science. 2013; 3(2):42-52.

30. McGregor GR, Markou MT, Bartzokas A, Katsoulis BD. An evaluation of the nature and timing of summer human discomfort in Athems, Greece. Climate Research. 2002; 20(1):83-92.

31. Ahas R, Aasa A, Menzel A, Fedotova G, Scheifinger $H$. Changes in European springs, phenology. International Journal of Climatology. 2000;22(14):1727-1738.

32. Randolph SE. Evidence that climate change has caused "emergence" of tickborne diseases in Europe. International Journal of Medical Microbiology. 2004; 293(37):10-15.

33. Abdussalam FA, Andrew JM, Daniel FS, Vanja MD, Mary HH, Thomas MH, John $\mathrm{ET}$, Gregor CL. The impact of climate change on Meningitis in Northwest Nigeria: An assessment using Cmip5 Climate Model Simulations. American Meteorological Society. 2014;6:371-379.

34. Hobbins MT, Ramirez JA, Brown TC. Trends in pan evaporation and actual evapotranspiration across the conterminous US: Paradoxical or complementary? Geophysical Research Letters. 2004;31(13):1-5.

35. Roderick ML, Farquhar GD. Change in Australian pan evaporation from 1970 to 2002. International Journal of Climatology. 2004;24(9):1077-1090.

36. Zhang Y, Liu C, Tang Y, Yang Y. Trends in pan evaporation and reference and actual evapotranspiration across the Tibetan Plateau. Journal of Geophysical Research. 2007;112(D121110):1-12.

37. Wang $\mathrm{Y}$, Jiang $\mathrm{T}$, Bothe $\mathrm{O}$, Fraedrich $\mathrm{K}$. Changes of pan evaporation and reference evapotranspiration in the Yangtze River basin. Theoretical and Applied Climatology. 2007;90(1):13-23.

38. Bandyopadhyay B, Bhadra A, Raghuwnshi NS, Singh R. Temporal trends in estimates of reference evapotranspiration over India. Journal of Hydrologic Engineering. 2009; 14(5):508-515.

39. Ramirez B, Harmsen W. Water vapour flux in agroecosystems: Methods and models review. In L. Labedski, Evapotranspiration. 
2011;3-48. INTECH Open Access

Publisher.

40. Peterson TC, Golubev VS, Groisman PY. Evaporation losing its strength. Nature. 1995;337(6551):687-688.

41. Chattopadhyay N, Hulme M. Evaporation and potential evapotranspiration in India under conditions of recent and future climatic change. Agricultural and Forest Meteorology. 1997;87(1):55-74.

42. Xu C, Gong L, Jiang T, Chen D, Singh VP. Analysis of spatial distribution and temporal trend of reference evapotranspiration and pan evaporation in Changjiang (Yangtze River) catchment. Journal of Hydrology. 2006;327(1-2):8193.

43. Song ZW, Zhang HL, Snyder RL, Anderson FE, Chen F. Distribution and trends in reference evapotranspiration in the North China Plain. Journal of Irrigation and Drainage Engineering. 2010;136(4): 240-247.

44. Rim CS. A Sensitivity and error analysis for the Penman Evapotranspiration model. KSCE Journal of Civil Engineering. 2004; 8(2):249-254.

45. Isikwue CB, Audu OM, Isikwue OM. Evaluation of evapotranspiration using FAO Penman-Monteith method in Kano Nigeria. International Journal of Science and Technology. 2014;3(11):698703.

46. Isikwue B, Dandy S, Audu M. Testing the performance of some empirical models for estimating global solar radiation over Makurdi, Nigeria. Journal of Natural Sciences Research. 2013;3(5):165-170.

(c) 2017 Abdussalam and Zaharaddeen; This is an Open Access article distributed under the terms of the Creative Commons Attribution License (http://creativecommons.org/licenses/by/4.0), which permits unrestricted use, distribution, and reproduction in any medium, provided the original work is properly cited. http://sciencedomain.org/review-history/19646 